\title{
DEFICIENCIES IN NEW ZEALAND DELEGATED LEGISLATION
}

\author{
Rt Hon Sir Geoffrey Palmer*
}

In this article, the author, a former Minister of Justice and Prime Minister, examines the history and role of statutory regulations. Processes for reviewing regulations, especially through the Parliamentary Regulations Review Select Committee, have been significant in offering protection against undesirable regulation-making. The courts have played a lesser role in this regard and the author calls for them to be "a little more robust in their approach to delegated legislation". The development of a third tier of law-making, by the use of so-called "rules", is worrying, as these rules receive the same scrutiny as regulations neither before nor after their making. The author recommends that either we abandon making such rules or we introduce processes which are more formal and transparent. At present, "the coherence of our legal system is threatened".

\section{INTRODUCTION}

At some points in its history New Zealand has been a constitutional innovator in extraordinarily extensive use of delegated or subordinate legislation. ${ }^{1}$ New Zealand has not been an innovator in providing for checks and balances against the excessive or inappropriate use of delegated legislation. It now has important checks in the form of the Regulations Review Select Committee of Parliament and the Regulations (Disallowance) Act 1989, but these protections arrived after the period of greatest reliance on delegated legislation.

* Honorary Lecturer in Law, Victoria University of Wellington; Partner, Chen \& Palmer, Barristers \& Solicitors, Wellington; Adjunct Professor of Law, University of Iowa.

1 The Economic Stabilisation Act 1948 enabled the government to control prices, wages, interest rates and to take almost every conceivable measure short of raising taxes. More than 200 regulations were made under that statute, driving one analyst to the conclusion that "the coherence of the constitution is breaking down" D Shelton "Government, the Economy and the Constitution" unpublished LLM thesis, Victoria University of Wellington, 1980. See also the Public Safety Conservation Act 1932 (now repealed) which allowed regulations to be made prohibiting any act, once a proclamation of emergency had been made. 
For too long New Zealand was an "executive paradise" in which the use of delegated legislation was a necessary means of efficiently implementing the power of the executive. ${ }^{2}$ Now, in an era of a mixed-member proportional electoral system, where minority Governments can and do occur, it may reasonably be expected that not only will there be a greater temptation to govern through delegated legislation under the control of the Executive Government but there may also be greater parliamentary scrutiny of the practice. Curiously delegated legislation has not attracted much interest from New Zealand lawyers in recent years despite its intense practical importance. ${ }^{3}$

The constitutional interest in delegated legislation arises from the fact that it is law, but it is not law made by Parliament. Noone doubts that Parliament has, as the Constitution Act 1986 puts it "full power to make laws." ${ }^{4}$ The issue of prime importance with delegated legislation is the degree to which Parliament should keep control of the law-making power so that democratically elected and accountable members of Parliament retain control over the content of the law. Delegated legislation is complicated by the fact that all three branches of Government have a contribution to make to it. Parliament makes the laws that allow delegated legislation to be made and scrutinises its use through the Regulations Review Select Committee. The Executive Government determines the content and substance of delegated legislation. The courts have powers not only to interpret it but also to strike it down if it is ultra vires the empowering statute.

There were 461 regulations made in New Zealand in 1998 - a record. Not even in the days of the Economic Stabilisation Act 1948, now happily repealed, did New Zealand ever approach a number of regulations to match 1998. A cursory analysis of the content of the 1998 regulations indicates that many of them are matters of detail and not of great significance. They do not appear to challenge the orthodox theory that regulations deal with matters of detail and technical issues with administrative machinery provisions that cannot conveniently be placed in statute. ${ }^{5}$

2 The phrase "executive paradise" was coined by Professor Leslie Zines Constitutional Change in the Commonwealth (Cambridge University Press, Cambridge, 1991) 47.

3 Philip A Joseph Constitutional and Administrative Law in New Zealand (The Law Book Company, Sydney, 1993) 210, 218-220, 449-450, 645-648, 745-787; Matthew Palmer and Geoffrey Palmer Bridled Power (Oxford University Press, Auckland, 1997) 167-183; Philip A Joseph "Delegated Legislation in New Zealand" (1997) 18 Statute LR 85; Desmond J Hewitt The Control of Delegated Legislation: Being a Study of the Doctrine of Ultra Vires in Relation to the Legislative Powers of the Executive Government with Special Reference to Great Britain, Australia, New Zealand and Canada (Butterworth, Wellington, 1953).

4 Constitution Act 1986, s 15

5 "Report of the Delegated Legislation Committee" (Algie Report) [1962] AJHR I 18; "Report of the Committee on Ministers' Powers" (1932, Cmd 4060). 
The purpose of this article is to outline recent developments in New Zealand in the field of delegated legislation and point out some serious deficiencies that have developed. This involves analysing the changes made by statutes passed in 1989, particularly the Regulations (Disallowance) Act 1989. It requires an examination of the powers of the Regulations Review Select Committee of Parliament that was established in 1986 and its record of scrutiny. Recent developments regarding a new species of delegated legislation, "deemed regulations", are scrutinised. This latter issue involves important questions concerning access to law by members of the public. Some developments in the United States are also examined for light they may shed on what is happening in New Zealand. Finally, some suggestions are made as to changes which would work to preserve orthodox constitutional understandings about delegated legislation.

\section{THE HISTORY OF PROTECTIONS AGAINST DELEGATED LEGISLATION}

The Regulations Act 1936 was designed to improve access to the law. It provided for the printing and publishing of regulations. Prior to that time, the text of regulations had been published in the New Zealand Gazette buried in the bulk of miscellaneous Government notices and announcements. From a practical point of view, the Gazette was an inconvenient reference source. ${ }^{6}$ Under the new system, regulations were first issued in loose sheets and then published in the form of a separate annual volume. It took some years before they became multiple volumes. ${ }^{7}$

There was a significant development in 1962 when a special Select Committee chaired by Speaker Algie, a former Law Professor, made a report. ${ }^{8}$ The Committee reported that a new objective form of empowering clause should be used in regulations. A new standard formula empowering clause had been drafted by Mr D A S Ward in 1961, the then Chief Law Draftsman, and it was approved by the Committee. Subjective empowering provisions authorising the Governor-General to make "such regulations as may in his opinion be necessary for giving full effect to the provisions of this Act and for the due administration thereof" had been common up to that point with specific purposes also being stated but not in such a way as to limit the general power. Subjective empowering provisions had made it difficult for the courts to strike down regulations. The new formula was:

6 The Law Book Company of New Zealand Ltd published thirteen volumes of their series Rules, Regulations and By-Laws made under the New Zealand Statute. Volume I covered the period 19101914 and the final volume 1935-36. With the commencement of publication of the official Statutory Regulations series, the private venture appears to have ceased.

7 Two volumes first appeared in 1954 and three in 1968.

8 "Report of the Committee on Delegated Legislation" [1962] AJHR I 18. 
The Governor-General may from time to time, by Order in Council, make regulations for all or any of the following purposes:

The Algie Committee thought the jurisdiction of the courts should not be ousted by a subjective formula. ${ }^{9}$

The Algie Committee also recommended that all regulations should be laid on the Table of the House and, further, that the Statutes Revision Committee of Parliament should be empowered to consider regulations referred to it and to determine whether the House's attention should be drawn to those regulations.

The Standing Orders were amended and the grounds for reviewing regulations resemble those which are now contained in Standing Order 197. However the procedures that allowed the Statutes Revision Committee to look at regulations were used on only eleven occasions between 1962 and 1985.

Further developments in protections against delegated legislation occurred in the 1980s. The Fourth Labour Government's Open Government policy contained the following plank: ${ }^{10}$

All regulations will be automatically referred to a special new parliamentary committee.

Public hearings may be held. The Committee will be given power to recommend to

Parliament that regulations be disallowed.

It was considered important to improve both access to the law and parliamentary scrutiny of delegated legislation in New Zealand. In order to implement Labour's policy, on 17 August 1984 the House of Representatives ordered the Statutes Revision Committee to "consider and recommend to the House such amendments to Acts of Parliament, Regulations, Standing Orders and other procedures relating to delegated legislation as would enable the effective and comprehensive scrutiny and control of such legislation consonant with the principle of the supremacy of Parliament. ..."11

The inquiry generated 19 submissions, the preponderance of opinion being that the existing measures were inadequate to ensure effective scrutiny of delegated legislation. The Committee recommended that:

9 In 1990, the Regulations Review Committee had occasion to review the type of empowering provisions in general use in New Zealand and found the 1961 formulation satisfactory. Neither did it object to the inclusion of a non-specific empowering provision in some bills: "Providing for such other matters as are contemplated by or necessary for giving full effect to the provisions of this Act or its due administration". "Report of the Regulations Review Committee on Inquiry into the Drafting of Empowering Provision in Bills" [1990] AJHR I 16, 3-5.

10 Geoffrey Palmer Unbridled Power (2ed, Oxford University Press, Auckland, 1987) 286.

11 "First Report of the Statutes Review Committee on Delegated Legislation" [1984-85] AJHR I 5. 
- Standing Orders be changed to provide that all regulations should stand automatically referred to a new Select Committee - the Regulations Review Committee;

- The Committee be empowered to consider draft regulations referred by Ministers;

- The Committee consider regulation making powers contained in all Bills and report to other Committees where requested;

- The Committee have power to bring any matter relating to regulation to the notice of Parliament;

- The Committee have power to initiate a review of any regulation;

- Unanimity be required before a complaint could be rejected by the Committee without a hearing of the complaint;

- There be nine specific grounds upon which regulations could be drawn to the attention of the House.

The recommendations and the policy were advanced by two means: changes to the Standing Orders of the House of Representatives and, subsequently, by passage of the Regulations (Disallowance) Act 1989. The Acts and Regulations Publication Act was also passed in 1989.

\section{CURRENT PROTECTIONS AGAINST DELEGATED LEGISLATION}

\section{A Executive Branch}

The Cabinet Office Manual devotes a whole chapter to the subject of legislation and regulations. ${ }^{12}$ It requires that "the Minister responsible for an item on the Executive Council Agenda must be present at Executive Council to answer any queries from the Governor-General or must have briefed another Minister who will be present". The Manual also sets out a number of rules about the making of Orders in Council. These rules deal with the need to pass regulations at all, the desirability of consultation, the need for consultation within Government and the need for Cabinet approval of the underlying policy.

The Manual requires Parliamentary Counsel Office ("PCO") to consider whether regulations are within the powers granted in the Act and anticipates that $\mathrm{PCO}$ will do the drafting. ${ }^{13}$ It has been the practice for many years in New Zealand for PCO to draft all Government Bills and statutory regulations. This practice is designed to produce

12 New Zealand Government Cabinet Office Manual 1996, Chapter 5.

13 Cabinet Office Manual paras 5.57, 5.61. 
consistency in style. PCO also drafts some other instruments such as Orders in Council appointing Commissions of Inquiry. It drafts all the instruments that fall within the definition of "regulation" in section 2 of the Regulations (Disallowance) Act 1989.14

The Manual also encourages Departments to prepare a schedule of regulations likely to be required each year. ${ }^{15}$ Cabinet looks at all regulations before they go to the Executive Council and in recent times they have also been vetted by the Legislation Committee of Cabinet before going to Cabinet. ${ }^{16}$ But ministers tend to give priority to the political issues of the day and do not see themselves as watchdogs over subordinate legislation.

While the provisions in the Cabinet Office Manual no doubt offer some deterrent to public servants who advise that regulations be made, the obstacles do not appear to be as substantial in practice as they are in theory.

\section{B Parliament}

Parliamentary checks against delegated legislation, however, have developed markedly, although later than in most other Commonwealth jurisdictions, particularly Australia. ${ }^{17}$ There were none until 1962 in New Zealand when the Algie Committee's recommendations were implemented.

\section{Regulations Review Committee}

In 1986 when the Standing Orders were reviewed a new Select Committee was established - the Regulations Review Committee. The Committee has terms of reference that give full power to examine all features of regulations and to hear complaints made by the public concerning them. The grounds upon which regulations can be drawn to the attention of the House are important, and are contained in Standing Order 197:

197 Drawing attention to a regulation - (1) In examining a regulation, the committee considers whether it ought to be drawn to the special attention of the House on one or more of the grounds set out in paragraph (2).

(2) The grounds are, that the regulation-

14 Statutes Drafting and Compilation Act 1920 establishes the office.

15 Cabinet Office Manual para 5.65.

16 Cabinet Office Manual paras 5.55-5.61, 5.69-5.71.

17 See D J Whalan "Scrutiny of Delegated Legislation by the Australian Senate" (1991) 12 Statute Law Review 87; Victor Perton, MP "Subordinate Legislation" Paper presented to the 1998 Public Law Conference, Canberra, 7 November 1998, www.vicnet.net.au/ victorp. For the position in Britain see J D Hayhurst and Peter Wallington "The Parliamentary Scrutiny of Delegated Legislation" [1998] Public Law 547. 
(a) is not in accordance with the general objects and intentions of the statute under which it is made:

(b) trespasses unduly on personal rights and liberties:

(c) appears to make some unusual or unexpected use of the powers conferred by the statute under which it is made:

(d) unduly makes the rights and liberties of persons dependent upon administrative decisions which are not subject to review on their merits by a judicial or other independent tribunal:

(e) excludes the jurisdiction of the courts without explicit authorisation in the enabling statute:

(f) contains matter more appropriate for parliamentary enactment:

(g) is retrospective where this is not expressly authorised by the empowering statute:

(h) was not made in compliance with particular notice and consultation procedures prescribed by statute:

(i) for any other reason concerning its form or purport, calls for elucidation.

In the time that the Regulations Review Committee has existed it has been busy, indicating that there was a need for a specialist Committee. ${ }^{18}$ It is now an established constitutional convention that the Committee will be chaired by an Opposition MP, and unlike most Committees political considerations tend not to figure because the Committee does not deal with substantive policy issues. It acts in a bi-partisan manner. It is serviced by qualified legal counsel engaged by the Clerk of the House. It has been an active Committee.

The Standing Orders provisions concerning complaints are novel. A complaint can be made by a member of the public by letter. The Committee must, unless it unanimously decides to the contrary, give the complainant an opportunity to address the Committee on the regulation. Following that preliminary consideration, if the Committee considers the complaint raises a prima facie case under the grounds set out in the Standing Orders, it launches a full inquiry. In addition, the Committee can and does investigate regulations without a complaint being made. The Committee's inquiries can be lengthy and involve a number of written submissions. ${ }^{19}$ The nine grounds for complaints set out in Standing

18 For more detail on its activity, see David McGee Parliamentary Practice in New Zealand (2 ed, GP Publications, Wellington, 1994) 406-423.

19 The writer was involved in one inquiry in which the complainant filed three extensive sets of legal submissions with the Committee and was heard three times. 
Order 197 are much wider than the grounds upon which a regulation can be impugned before a court.

The Committee has drawn regulations to the attention of the House on numerous occasions. $^{20}$ See Appendix 1 at the end of the article for a reference to all the complaints the Committee has dealt with. It is important to note, however, that the work of the Committee is much wider than dealing with complaints. The Government does not always respond favourably to all the recommendations. But the record of the Committee taken as a whole has been a good one. Its activities must surely act as a deterrent to the promulgation of regulations that are inappropriate. The Committee has built up a series of reports that are a useful repository on how the powers are likely to be exercised.

In sum, the Regulations Review Committee has done a great deal of work in the years that it has existed, and the manner in which it has exercised its responsibilities has had a significant influence on the conduct of the Executive Government in making regulations.

\section{Regulations (Disallowance) Act 1989}

The Regulations (Disallowance) Act 1989 was the second means by which the recommendations of the 1984 inquiry were implemented. The definition of "regulation" is of substantial importance since it triggers the threshold for what may be disallowed under the Act, what may be reported on under the Standing Orders of the House, and the requirements for publication as well. It had its origins in the Regulations Act 1936. The definition is as follows:

"Regulations" means-

(a) Regulations, rules, or bylaws made under the authority of any Act-

(i) By the Governor-General in Council; or

(ii) By any Minister of the Crown:

(b) Instruments, other than Acts of Parliament, which revoke regulations:

(c) Orders in Council, Proclamations, notices, Warrants, and instruments of authority made under any Act by the Governor-General in Council or by any Minister of the Crown which extend or vary the scope or provisions of any Act:

20 Report of the Regulations Review Committee "Investigation into the Disputes Tribunal Amendment Rules 1997 and the Disputes Tribunal Amendment Rules 1998" [1998] AJHR I 16L; Report of the Regulations Review Committee "Investigation into the Biosecurity (Rabbit Calcivirus) Regulations 1997" [1998] AJHR I 16E; Report of the Regulations Review Committee "Investigation into the Transport (Drivers Licensing) Amendment Regulations" [1998] AJHR I 16I; Report of the Regulations Review Committee "Investigation into the Gaming and Lotteries (License Fees) Regulations 1997" [1998] AJHR I 16H. 
(d) Orders in Council bringing into force, or repealing, or suspending any Act or any provisions of any Act:

(e) Rules or regulations made under any Imperial Act or under the prerogative rights of the Crown and having force in New Zealand:

(f) Instruments deemed by any Act to be regulations for the purposes of the Regulations Act 1936 or this Act.

There are some intriguing issues about which instruments are caught by these provisions and which are not, but they will not be analysed here. But it is important to note that (f) applies the provisions of the Act to deemed regulations. There are, however, as will be discussed later, an increasing number of statutory provisions that deem instruments to be regulations for the purposes of the Regulations (Disallowance) Act 1989 but not for the purpose of the Acts and Regulations Publications Act 1989.

One of the key provisions in the Regulations (Disallowance) Act is section 5(1):

The House of Representatives may, by resolution, disallow any regulations or provisions of regulations.

The House can also amend any regulations, revoke them and substitute others. ${ }^{21}$ That power is re-enforced by statutory provisions that prevent parliamentary manoeuvring to avoid the resolution being put to the House. Specifically, the Act provides that if a motion to disallow a regulation has not been called on or disposed of within 21 sitting days then "the regulations or provisions specified for disallowance in the motion shall thereupon be deemed to have been disallowed. ${ }^{22}$ Disallowance has the same effect as revocation. ${ }^{23}$

The Act also provides that all regulations shall be laid before the House of Representatives not later than the sixteenth sitting day of the House after the day on which they were made. ${ }^{24}$ The statute contains no sanction for non-compliance with this provision. It may be argued, therefore, that it is merely directory. On the other hand, where there is a power to disallow as now exists in New Zealand, it may be mandatory. ${ }^{25}$

The Regulations (Disallowance) Act provides a potentially drastic parliamentary remedy. It is so potent that there is perhaps a reluctance to use it even in the MMP era.

21 Regulations (Disallowance) Act 1989, s 9.

22 Above n 21, s 6.

23 Above n 21, s 7.

24 Above $\mathrm{n} 21, \mathrm{~s} 4$.

25 Philip A Joseph Constitutional and Administrative Law in New Zealand (The Law Book Company, Sydney, 1993) 766. 
There is a feeling among Governments that they must win all votes even votes that do not involve matters of confidence. The Regulations Review Committee appears to be much more willing to draw regulations to the special attention of the House than it is to recommend use of the heavy artillery in the Regulations (Disallowance) Act. In fact, there has never been a successful motion for disallowance. A motion was moved in 1998, but it failed. ${ }^{26}$

\section{Acts and Regulations Publication Act}

While the Regulations (Disallowance) Act was designed as a check against the inappropriate use of regulations, the companion measure, the Acts and Regulations Publication Act 1989, was concerned with access to law issues. It requires the Chief Parliamentary Counsel under the control of the Attorney-General to arrange for the printing and publication of:

- $\quad$ Every Act enacted by Parliament;

- All regulations;

- Reprints of Acts and Regulations;

- $\quad$ Reprints of Imperial Acts.

There are a number of specific requirements for regulations. All regulations must contain printed references to the Act or other authority under which they were made. ${ }^{27}$ They must be available for purchase by the public at places designated by the AttorneyGeneral, but they can also be made available at other places. ${ }^{28}$ They must be made available for sale at a reasonable price. Regulations must be identified by a number as part of an annual series of regulations. ${ }^{29}$ The Chief Parliamentary Counsel is also required to arrange for the publication in the Gazette of a notice showing the title of the regulations, the date they were made, the Act or authority under which they were made, the number allocated to the regulations, a place where they may be purchased and such other information as he or she thinks appropriate. ${ }^{30}$ Instruments that are not regulations may, if the Attorney-General or Chief Parliamentary Counsel so desires, be published as if they were a regulation. ${ }^{31}$

26 (11 November 1998) 573 NZPD 13104-13119.

27 Section 8.

28 Section 9

29 Section 11

30 Section 12.

31 Section 14. 
There is a specific provision relating to the incorporation of amendments to reprints of regulations. $^{32}$ The Act also amends the Evidence Act 1908 to provide that judicial notice shall be taken by all courts and persons acting judicially of all regulations. Copies of reprints are deemed, unless the contrary is proved, to correctly state the law made in the regulations.

Statutory provisions that provide for public access to delegated legislation ought not to be regarded as a dead letter. The provisions are not merely grace and favour provisions. Section 13 of the Acts Interpretation Act 1924 provides that Acts of the General Assembly "shall be procurable by purchase at the office of the Government Printer." In Victoria University of Wellington Students Association v Shearer (Government Printer) Wild CJ stated: ${ }^{33}$

The Crown is broadly responsible for making the text of enactments available for public information. People must be told what Parliament is doing and must be able to read the letter of the law.

He did not apply that principle to the text of the Judicature Act 1908, the second schedule of which contained the Rules of Civil Procedure. He reasoned that the provision fell short of designating the Government Printer to perform activity that should be enforced by mandamus. He noted that the duty under section 3 of the Regulations Act 1936 was more explicit.

The State is under an obligation to make the law publicly available and in New Zealand that obligation is performed in an imperfect and cumbersome manner. Perhaps improvements will occur - there have been two important developments. The first was a 1996 report of the Regulations Review Committee on access to regulations. ${ }^{34}$ It made various recommendations, a number of which the Government rejected. ${ }^{35}$ PCO is also clearly concerned about the current situation. It has published a discussion paper Public Access to Legislation. ${ }^{36}$ Despite these developments, the prospects of decisive action by the Government cannot be regarded as likely. The issue enjoys no political priority. But developments concerning "deemed regulations" discussed later in this article make the issue urgent.

32 Section 15

33 [1973] 2 NZLR 21, 23.

34 Regulations Review Committee "Investigation into Access to Regulations" [1996] AJHR I 16J.

35 "Government Response to the Report of the Regulations Review Committee on Investigation into Access to Regulations" Presented to the House of Representatives in accordance with Standing Order 251 [1996] AJHR A5. 


\section{Courts}

The contribution of the courts in New Zealand to checking the use of the regulationmaking power in recent years has not been great. In relation to regulations passed under the Economic Stabilisation Act, the Court of Appeal did once upset the capacity of the then Government to, in the immortal words of Sir Robert Muldoon in 1976: "... do anything provided you can hang your hat on economic stabilisation". 37 The Court of Appeal held that regulations made under the Economic Stabilisation Act could not override another statute. ${ }^{38}$ But the result was immediately overturned by rushed legislation.

It is worth noting, though, that some of the New Zealand cases on the books are memorable in the degree of analytical complexity to which they will go into in order to defeat inappropriate powers of the Executive. ${ }^{39}$ Since 1986 when the Regulations Review Committee was established, the pages of the New Zealand Law Reports do not reveal great judicial activity in declaring regulations invalid.

A search of the databases reveals only fifteen ultra vires cases in the New Zealand courts since 1986 and only two of those were reported in the law reports, ${ }^{40}$ the remainder being unreported. Yet the New Zealand courts have been rather bolder in reviewing local authority by-laws when compared to Government regulations. ${ }^{41}$ It is not apparent why the types of delegated legislation should be distinguished from one another for the purpose of legal challenge. An Australian commentator has reported that New Zealand courts "have felt no constraint in ruling local authority by-laws invalid as unreasonable." 42

The New Zealand cases concerned with challenges to subordinate legislation indicate a distinction between by-laws and other subordinate instruments. While challenges to bylaws on the basis of unreasonableness have been permitted, the ground has frequently been denied in respect of regulations. Thus, in F E Jackson $\mathcal{E}$ Co Ltd $v$ Collector of Customs: ${ }^{43}$

A Court is not entitled to disallow regulations which appear to be within the intention of

Parliament merely because the Court thinks them unreasonable ... The duty of the Court is to

37 R Lewis "How Mr Muldoon Waved a Big Stick Over the Unions" The Times, 14 April 1976, 18.

38 Combined State Unions v State Services Coordinating Committee [1982] 1 NZLR 742.

39 Reade v Smith [1959] NZLR 996.

40 Police v MDR [1997] DCR 39; Wielgus v Removal Review Authority [1994] 1 NZLR 73.

41 McCarthy v Madden (1914) 33 NZLR 1251; Craig v Hutt Valley E Bays Metropolitan Milk Board [1956] NZLR 168.

42 D C Pearce Delegated Legislation in Australia and New Zealand (Butterworths, Sydney, 1977) 205.

43 [1939] NZLR 682, 720. 
search for the intention of Parliament and to support regulations that keep within that intention, and to disallow such as do not.

Similarly, in Cossens \& Black Ltd v Prebble, ${ }^{44}$ the Court found:

The approach to the review of statutory regulations has been well settled in New Zealand for 50 years. It is common ground that a regulation may be attacked as being ultra vires the objects and intention of the delegating power under which the regulation purports to be made. It cannot be attacked on the grounds of unreasonableness.

However, some confusion is in part due to the existence of a broader principle of unreasonableness available in respect of by-laws. For example, in Courtville Ltd v Paull the Supreme Court stated that: ${ }^{45}$

But, although prima facie within [the legislation-making] powers, the by-law has still to be examined from the points of view of alleged unreasonableness and uncertainty, because, if either of these criticisms be established, the by-law is bad, since the Legislature does not authorise local authorities to make by-laws that are unreasonable or uncertain.

Broadly, the New Zealand case law suggests that unreasonableness exists as a separate ground in respect of bylaws but not in respect of regulations. But a different approach was taken by a discussion by McGechan J in Turners $\mathcal{E}$ Growers Exports Ltd $v$ Moyle, ${ }^{46}$ in which the Court found that unreasonableness could be found in terms of the scope of the empowering legislation. He put the matter this way:

In principle, I prefer the view that regulations can be attacked as ultra vires an empowering statute if the regulations are so unreasonable that their making would not have been contemplated by Parliament as empowered by that statute. In such situations, as a matter of ordinary interpretation of Parliamentary intention, the empowering statute is read down accordingly. Such extreme situations will not be frequent. If, by contrast, a regulation does not fall into such an extreme category, and is within possible Parliamentary contemplation, then it is not open to attack on the basis it is "unreasonable". Possibly, a sufficient degree of unreasonableness may appear ex facie. A regulation prohibiting employment of all teachers with red hair would be an example. More often, extreme unreasonableness may emerge only as a matter of actual effects which are so unreasonable as to invite inference the regulations were not empowered. It is, of course, always open to Parliament to exclude such an approach by the Court by expressly enacting that the regulations concerned shall not be invalid upon the grounds such are unreasonable.

4411 August 1987, unreported, High Court, Wellington Registry, A 318/84, per Heron J.

45 [1950] NZLR 18, 27.

4615 December 1988, unreported, High Court, Wellington Registry, CP 720/88, per McGechan J. 
The United Kingdom case law in this area has, to some extent, avoided this distinction, as has relevant case law in Australia. In both jurisdictions, it has been held that the enhanced political accountability of much subordinate legislation may raise the threshold for findings of unreasonableness, but that the ground is nonetheless available. It must, however, be emphasised that unreasonableness in the context of subordinate legislation has frequently been addressed in terms of the objectives of the empowering legislation, as in Turners $\mathcal{E}$ Growers, rather than as a distinct ground.

The United Kingdom approach begins with Kruse v Johnson. ${ }^{47}$ That case is authority for the proposition that unreasonableness, albeit potentially of a higher standard, is available as a ground of review for subordinate legislation. There, Lord Russell CJ found that although the standard for review was high, particularly where elected bodies were concerned, unreasonableness would be available as a ground: ${ }^{4}$

I think courts of justice ought to be slow to condemn as invalid any by-law, so made under such conditions, on the ground of supposed unreasonableness.

$\cdots$

If, for instance, they were found to be partial and unequal in their operation as between classes; if they were manifestly unjust; if they disclosed bad faith; if they involved such oppressive or gratuitous interference with the rights of those subject to them as could find no justification in the minds of reasonable men, the court might well say, "Parliament never intended to give authority to make such rules; they are unreasonable and ultra vires". But it is in this sense, and in this sense only, as I conceive, that the question of unreasonableness can properly be regarded.

These requirements were restated by Diplock LJ in Mixnam's Properties Limited $v$ Chertsey Urban District Council ${ }^{49}$ in respect of subordinate legislation generally, in slightly different terms. There, the Court emphasised the limited scope of unreasonableness in this context: ${ }^{50}$

The various special grounds upon which subordinate legislation has sometimes been said to be void - for example, because it is unreasonable; because it is uncertain; because it is repugnant to the general law or to some other statute - can, I think, today be properly regarded as being particular applications of the general rule that subordinate legislation, to be valid, must be shown to be within the powers conferred by the statute. Thus, the kind of

$47 \quad[1898] 2$ QB 91.

48 Kruse above $\mathrm{n} 47,99-100$.

49 [1964] 1 QB 214.

50 Mixnam's Properties Ltd above n 49, 237. 
unreasonableness which invalidates a bylaw is not the antonym of "reasonableness" in the sense of which that expression is used in the common law, but such manifest arbitrariness, injustice or partiality that a court would say: "Parliament never intended to give authority to make such rules; they are unreasonable and ultra vires"; Kruse v Johnson per Lord Russell CJ.

The more recent decision of the Court of Appeal in $R v H$ M Treasury ex $p$ Smedley ${ }^{51}$ involved a challenge to an Order in Council under the European Communities Act 1972 (UK). Under that Act, the Order required the approval by resolution of both Houses of Parliament before its declaration. The applicants contended that the Order in question proceeded from a misinterpretation of the empowering statute. Sir John Donaldson MR stated the general principles relating to review: ${ }^{52}$

... legislation by Order in Council, statutory instrument or other subordinate means is in a quite different category, not being Parliamentary legislation. This subordinate legislation is subject to some degree of judicial control in the sense that it is within the province and authority of the courts to hold that particular examples are not authorised by the statute, or as the case may be by the common law, and so are without legal force or effect.

Sir John Donaldson MR proceeded to consider whether the interpretation upon which the Order was based was one that "could properly" be made and thus whether the Order was intra vires.

By contrast, Slade LJ made some limited reference to reasonableness as a ground. He held that, notwithstanding the involvement of Parliament: ${ }^{53}$

... I can see no reason why the exercise of the last mentioned discretion [whether or not to make the Order] given to Her Majesty in Council should not be open to attack in the courts by the process of judicial review, subject to the stringent restrictions on any such attack imposed by what has come to be known as the Wednesbury principle.

The ground of unreasonableness appears to be available, but on a restricted or indirect basis. Wade and Forsyth ${ }^{54}$ describe $R v$ Customs and Excise Commissioners ex $p$ Hedges and Butler $L t d^{55}$ in terms of unreasonableness, but it must be recognised that the ground is mentioned only in passing and that the decision is primarily concerned with the breadth of the empowering statute.

\footnotetext{
$51 \quad[1984] 1$ QB 657.

52 Smedley above $\mathrm{n} 51,666-667$

53 Smedley above $\mathrm{n} 51,672$.

54 Administrative Law (7 ed Clarendon Press, Oxford, 1994) 881.

55 [1986] 2 All ER 164.
} 
Although Australian courts had held that unreasonableness would not issue against subordinate legislation, several recent decisions have reversed this earlier position. In South Australia $v$ Tanner, ${ }^{56}$ the High Court noted the development of a less deferential approach to subordinate legislation. The majority decision of Wilson, Dawson, Toohey and Gaudron JJ found the relevant test to be "whether the regulation is capable of being considered as reasonably proportionate to the pursuit of the enabling purpose", 57 thereby invoking the "reasonable proportionality" doctrine developed in the Tasmanian Dams decision.

In a separate decision, Brennan J stated the test for invalidity to be whether:

having regard to its operation in the circumstances to which it applies and to the statutory object to which it must be directed, the regulation could not reasonably have been adopted to achieve the object.

It is therefore possible to conclude that Australian case law has also adopted a ground of narrow unreasonableness in respect of subordinate legislation. This view is confirmed by Halsbury's Laws of Australia, ${ }^{58}$ which states that:

Doubt has been expressed as to whether unreasonableness is indeed an available ground of review in relation to the exercise of the delegated law-making power. However, there is ample authority for the availability of this ground of review ...

The test of unreasonableness ... found in Kruse v Johnson tends to be cited in cases of exercise of delegated law making power. In particular, the court may apply a test as to whether the delegated legislation is so oppressive or capricious that no reasonable mind could justify it. Delegated legislation will not be held unreasonable simply on the ground that it does not contain qualifications as to the exercise of a power ... If the court were to apply Wednesbury unreasonableness in such a manner it would be intruding into the merits of the administrative decision.

Despite the reservations expressed by the New Zealand Court of Appeal concerning unreasonableness as a ground for judicial review of administrative action, ${ }^{59}$ it is submitted that applying carefully calibrated unreasonableness tests to regulations as well as by-laws New Zealand would assist in preserving the constitutional orthodoxy.

$56 \quad(1989) 166$ CLR 161.

57 South Australia above n56, 165.

58 Halsbury's Laws of Australia, \$10-2300.

59 Wellington City Council v Woolworths New Zealand Ltd [1996] 2 NZLR 436. 
There are also possibilities involved in challenging regulations on the grounds that the provisions in them are contrary to the New Zealand Bill of Rights Act 1990. It can be persuasively argued that a regulation is not an enactment in terms of section 4 of the Bill of Rights Act. But this issue is beyond the scope of this article.

The public law point that matters for present purposes is the idea that the courts have the scope to exercise more control over regulations in New Zealand than they have been doing. It would be a useful contribution if that potential were to be exercised. That is particularly the case given the developments discussed in the next section of this article.

\section{DEEMED REGULATIONS}

The quantity of law required by the Executive Branch and made by it seems, like water, to find its own level. When parliamentary checks and other measures have been implemented to discourage Government by regulation the phenomenon simply metamorphoses into new forms and takes on new characteristics. In recent years a new species of delegated legislation, "deemed regulations", has emerged. They are frequently called rules. There are more than forty statutes that allow this form of delegated legislation to be made. Many deemed regulations are not published in the Statutory Regulations series that is produced and sold by the Government. They are not drafted by PCO as regulations are. Nor are they agreed to by Cabinet. Usually they are agreed to by one Minister and become law upon his or her signature.

The paradigm case for the purposes of this article is contained in the Land Transport Act 1998, some of the relevant provisions of which are as follows:

152. Minister's general power to make ordinary rules- The Minister may from time to time make rules ("ordinary rules") for the purposes of or concerning-

(a) Safety and licensing, including technical requirements and standards, for any form of transport within the land transport system:

(b) A matter related or reasonably incidental to functions of the Authority or Director under this Act:

(c) Any other matter contemplated by a provision of this Act.

153. Rules concerning road user behaviour- Without limiting the general power to make rules under section 152, ordinary rules may- 
(a) Set out standards and requirements concerning road user behaviour, including standards and requirements concerning the conduct of drivers, pedestrians, and other persons using roads:

(b) Regulate traffic of all classes (including vehicular, pedestrian, and animal traffic), and prohibit traffic or a class of traffic, either absolutely or conditionally, on a specified road or specified class of road:

(c) Set out standards and requirements concerning the use of vehicle safety equipment by drivers, and passengers in or on vehicles:

(d) Regulate the movement of animals on roads.

161. Procedure concerning ordinary rules- (1) Every ordinary rule must-

(a) Be signed by the Minister; and

(b) Contain a statement specifying the objective of the rule and the extent of any consultation under subsection (2); and

(c) Set out fully the requirements of the rule, except where certain information is incorporated in the rule by reference under section 165 .

(2) Before making an ordinary rule, the Minister must-

(a) Publish in the Gazette, and in the daily newspapers published in Auckland, Hamilton, Wellington, Christchurch, and Dunedin, respectively, a notice of his or her intention to make the rule; and

(b) Give interested persons a reasonable time, which must be specified in the notice published under paragraph (a), to make submissions on the proposal; and

(c) Consult with such persons, representative groups within the land transport system or elsewhere, Government departments, and Crown entities as the Minister in each case considers appropriate.

(3) Every ordinary rule must be notified in the Gazette and be made available by the Authority for purchase by members of the public at a reasonable price, and the notification must specify a place where the rule is available for inspection free of charge and for purchase.

(4) Every ordinary rule comes into force 28 days after the date of its notification in the Gazette, or on such later day as may be specified in the rule or under section 163(3).

One highly significant feature of ordinary rules is that they are deemed to be regulations for some purposes. Section 160(6) provides: 
An ordinary rule is a regulation for the purposes of the Regulations (Disallowance) Act 1989, but is not a regulation for the purposes of the Acts and Regulations Publication Act 1989.

The result of that provision is to provide the constitutional justification for the entire rule structure. ${ }^{60}$ It ensures that Parliament retains ultimate control of the law through its capacity to disallow a rule by resolution. The question is whether this check is a sufficient or real one. Does it turn the Regulations (Disallowance) Act on its head by making rules regulations for the purpose of being disallowed so it can be argued that it is appropriate and safe to make rules rather than regulations in the first place?

The good news is that the Regulations Review Committee has, of its own motion, launched an investigation into the new practice of making "deemed regulations" and a full report on the subject is expected in 1999. In August 1998 the Committee published a discussion paper Inquiry into Instruments Deemed to be Regulations. The report notes that increasing numbers of statutes have delegated to Government agencies the power to make legislation in the "form of rules, codes of practice, instructions, standards, notices, orders or in some other form". The Committee identified 47 statutory provisions which authorise the making of instruments which are deemed to be regulations. These include the land transport rules made under the provisions cited above, but also civil aviation and maritime transport rules, privacy Codes of Conduct made by the Privacy Commissioner, Legal Services Board Instructions and Penal Institutions Operational Standards. It appears that in launching its inquiry the Committee was influenced by submissions made in a hard fought complaint to the Committee about a Land Transport Rule concerning window tinting on vehicles, in particular, the allowable visible light transmittance levels on the side front windows of passenger vehicles. ${ }^{61}$

The Committee published a useful discussion paper when it began its inquiry into deemed regulations. ${ }^{62}$ It contains research into the extent of the phenomenon. In particular Appendix A to the paper contains a list of the instruments deemed to be regulations for the purposes of the Regulations (Disallowance) Act 1989. A second and shorter list is contained in Appendix B of the instruments deemed to be regulations for the purposes of the Regulations (Disallowance) Act 1989 but not for the purposes of the Acts and Regulations Publications Act 1989. The second list is set out below:

Instruments deemed to be regulations for the purposes of the Regulations (Disallowance) Act 1989 but not for the

60 Similar although not identical provisions were contained in the Land Transport Act 1993.

61 Report of the Regulations Review Committee "Complaint Relating to Land Transport Rule 32012Vehicle Standards (Glazing)" [1998] AJHR I 16K.

62 Regulations Review Committee, Discussion Paper "Inquiry into Instruments Deemed to be Regulations" 6 August 1998. 
purposes of the Acts and Regulations Publication Act 1989

\begin{tabular}{|c|c|c|}
\hline Empowering Act & Empowering Section & Type of Instrument \\
\hline $\begin{array}{l}\text { Airport Authorities Act } \\
1966\end{array}$ & $\begin{array}{l}\text { Section 9A(4) } \\
\text { (inserted by section } 6 \text { of } \\
\text { the Airport Authorities } \\
\text { Amendment Act 1997) }\end{array}$ & Guidelines \\
\hline Civil Aviation Act 1990 & Section 28 & Ordinary Rules \\
\hline Civil Aviation Act 1990 & Section 31 & Emergency Rules \\
\hline $\begin{array}{l}\text { Customs and Excise Act } \\
1996\end{array}$ & Section 288 & Ordinary Rules \\
\hline $\begin{array}{l}\text { Financial Reporting Act } \\
1993\end{array}$ & Section 33 & $\begin{array}{l}\text { Financial Reporting } \\
\text { Standards }\end{array}$ \\
\hline Food Act 1981 & Section 11I & Food Standards \\
\hline $\begin{array}{l}\text { Institute of Chartered } \\
\text { Accountants of New } \\
\text { Zealand Act } 1996\end{array}$ & Section 8 & $\begin{array}{l}\text { Rules of the Institute and } \\
\text { Code of Ethics }\end{array}$ \\
\hline Land Transport Act 1993 & Section 4 & Ordinary Rules \\
\hline Land Transport Act 1993 & Section 7 & Emergency Rules \\
\hline Legal Services Act 1990 & Section 97A & Instructions \\
\hline Legal Services Act 1990 & Section 158A & Instructions \\
\hline Legal Services Act 1990 & Section 158L & Instructions \\
\hline $\begin{array}{l}\text { Maritime Transport Act } \\
1994\end{array}$ & Section 451 & $\begin{array}{l}\text { Ordinary and Emergency } \\
\text { Rules }\end{array}$ \\
\hline $\begin{array}{l}\text { Medical Practitioners Act } \\
1995\end{array}$ & Section 125 & Ordinary Rules \\
\hline $\begin{array}{l}\text { Penal Institutions Act } \\
1954\end{array}$ & Section $10 \mathrm{~A}$ & Operational Standards \\
\hline $\begin{array}{l}\text { Penal Institutions Act } \\
1954\end{array}$ & Section 10ZG & Operational Standards \\
\hline
\end{tabular}




\begin{tabular}{|l|l|l|}
\hline Privacy Act 1993 & Section 50 & Code of Practice \\
\hline $\begin{array}{l}\text { Rating Valuations Act } \\
1998\end{array}$ & Section 5(6) & Rules \\
\hline $\begin{array}{l}\text { Smoke Free } \\
\text { Environments Act } 1990\end{array}$ & Section 32F & Code of Practice \\
\hline
\end{tabular}

Concerning the Land Transport Act 1998 it can be said that some road safety provisions are of such fundamental importance to people that they are unsuitable for delegated legislation. For example, the driving age and the question of fitness to drive are issues for Parliament and primary legislation. The problem is that some provisions are in the statute, some in the regulations, and some in the rules. This cannot be regarded as a satisfactory way to make law. For example, the Act says in section 25: "A person who is younger than 15 may not hold or obtain a driver licence." But section 26 says: "The Director may require applicants for a driver licence and holders of driver licences to undergo prescribed tests and examinations in accordance with the regulations and the rules".

It is hard to avoid an impression of legal confusion in respect of Part 11 of The Land Transport Act, which deals with Land Transport subordinate legislation. What is clear, however, is that rules will govern much of what is important in driver licensing. There is clearly a desire on the part of the regulators to have flexibility at the expense of legal certainty and clarity.

The method by which this task of legal regulation is being approached is fundamentally unsound. Appropriate levels of scrutiny and accountability are lacking for matters that involve important policy elements. In addition, efficiency and effectiveness gains will not be made. Moreover, the rule making process puts interested parties to considerable expense but with no guarantee that their input will be impartially considered. In this respect, the process imposes costs on industry.

Regarding expenses, it should not be overlooked that organisations involving themselves in the consultation process run by regulators such as the Land Transport Safety Authority incur significant costs. But there is no guarantee that their views will be given real weight by those who are formulating the rule. Costly and frustrating consultation with bureaucrats is no substitute for elected MPs looking at a proposed rule and assessing it before it becomes law. Moreover, there does not appear to be any defined process for amending rules. In the absence of such an explicit provision, it will presumably be necessary to go through the whole process for amendments.

Unlike the regulation making process, the rule making procedure does not contain any independent scrutiny. A series of public consultations are most certainly no substitute for that. As discussed above, regulations are governed by a detailed process laid out in the 
Cabinet Office Manual. One step in this process is scrutiny by PCO. PCO considers whether the regulations are within the regulation making powers granted under the Act. They also consider whether the regulations restrict individual freedom unreasonably or are otherwise undesirable from a legal perspective. If not, approval from the AttorneyGeneral is required before the regulations can be submitted to Cabinet. Regulations are certified by the Parliamentary Counsel before they go to Cabinet. ${ }^{63}$

PCO is an office of legal expertise. In addition, it is independent; it has no involvement with any of the policy issues involved. While there has been a tendency in recent years for Bills and regulations to be drafted outside PCO, the office retains control and that control is vital for quality to be maintained. By contrast, rules made under the Land Transport Act are only required to be reviewed by the Ministry of Transport and the Minister. There is public consultation but that does not amount to scrutiny. It merely requires that the Land Transport Safety Authority is informed of the views of interested parties. Thus, rules are not scrutinised by a detached body and do not receive any independent audit within the executive branch of Government unless the supervision exerted by the Ministry of Transport over the Land Transport Safety Authority can be counted as such scrutiny.

It is even more concerning that, unlike regulations, rules are not scrutinised by Ministers in Cabinet. Cabinet has an important role in the regulation-making process. As indicated above, the policy underlying proposed regulations must be approved by a Cabinet committee and Cabinet before drafting occurs. ${ }^{64}$ Once they are drafted, the regulations are again submitted to Cabinet and Cabinet must authorise submission of the regulations to the Executive Council for the regulations to be made by the GovernorGeneral in Council. ${ }^{65}$

In stark contrast, rules amount to law made by a single Minister. A draft rule is produced and there is an opportunity for public comment. Submissions are analysed and further drafts are prepared. The rule is then reviewed by the Ministry of Transport and passed into law by the Minister. Cabinet is not involved in rule making. Rules are therefore subject to remarkably little scrutiny. The impact of rules can be significant and wide-reaching, yet there is little or no chance for MPs to scrutinise them before they become law. Consequently, rules provide considerable potential for defective lawmaking. There is every chance in the processes used to make rules that elements of predetermination will affect regulators and there are insufficient checks against this. There is no opportunity for elected politicians, except for one Minister, to examine the issues before a rule is adopted. A single Minister is then asked to bear the political responsibility of

63 Cabinet Office Manual paragraphs 5.57, 5.61.

64 Above n63, 5.55.

65 Above n 63, 5.55-59. 
turning down a safety measure from an agency charged with safety tasks. There is no opportunity to ensure that the proposed rule is based on solid and reliable factual information and rigorous legal analysis.

In contrast with regulations, there is also no post-promulgation scrutiny of rules. After they are made, all regulations are examined by the Regulations Review Committee of the House of Representatives which considers whether they comport with basic legal and constitutional principles. There is no such requirement for rules. The only opportunity for elected lawmakers to address faulty rule-making is after the fact - through review by the Regulations Review Committee - in the event that there is a complaint.

Rules may be appropriate where the subject matter is technical. The Statutes Revision Committee (predecessor of the Regulations Review Committee) identified areas in which tertiary legislation could be justified: ${ }^{66}$

- Where the subject-matter of the legislation is extremely complicated and technical, and will be subject to regular updating in accordance with technological advances.

- Where for some particular reason there is a need for greater flexibility and speed in adapting to external circumstances that would not be satisfied by the use of more "normal" regulations.

That concession by the Committee appears to have led to the provision of rule making provisions for civil aviation that then migrated to other areas for which they were not suitable.

Furthermore, it needs to be borne in mind that in 1980 the Statutes Revision Committee decided that the Civil Aviation Regulation 1953, Amendment 22 should be drawn to the attention of the House because:

1 The regulations confer wide law-making power on a State servant without at the same time providing any safeguards against the abuse of that power; and

2 They fail to make provision for rights of appeal against decisions that could adversely affect a person's ability to gain his livelihood.

While many of the Civil Aviation Rules made pursuant to the Civil Aviation Act 1990 are highly technical and apply only to a narrow band of people engaged in aviation activities, some of them affect a broad segment of the public. For example, Rule 19.7(6) provides that no person who is obviously under the influence of intoxicating liquor, narcotics or drugs may enter or be carried in an aircraft. Breach of this rule has potential

66 Statutes Revision Committee "Report on the Remuneration (New Zealand Forest Products) Regulations and the Civil Aviation Regulations 1953, Amendment No 22" [1980] AJHR I 5A. The Civil Aviation Act 1990 contains authority to make rules, ss 28 and 31. 
application to many members of the public. Such a provision should not be in a rule, but a regulation.

It is also inappropriate for tertiary legislation to impose binding obligations that are enforceable by offences created by regulation (as authorised by $s 100(1)(b)$ and (c) of the Civil Aviation Act 1990). Three levels of law are bound to create confusion. The practice of stating the obligation in one place and the enforcement provision in another is common, for example, Codes of Practice made under the Health and Safety in Employment Act 1992. Both obligations should be in the same instrument and that instrument should be a regulation.

The choice of delegate has been addressed in an important report of the Legislation Advisory Committee. ${ }^{67}$ But the failure to clearly identify the principles to be applied in legislation and the processes to be followed means New Zealand is descending into a mire of legal complexity and confusion that has consequences not only for the constitution but also the rule of law.

There is one final cause for concern. The regulatory agencies in the transport area generally in New Zealand are Crown entities. Most of their work is not subject to the principles of ministerial responsibility. They are not subject to the controls of the State Sector Act 1988 nor the oversight of the State Services Commission.

\section{CAUTIONARY TALES FROM THE UNITED STATES}

The manner in which American administrative law has developed at both the state and federal level is dramatically different from Commonwealth jurisdictions. Many of the comparisons are due to the relative differences in the distribution of powers to the branches of Government. One consequence of the fusion of legislative and executive power in New Zealand is that through the Cabinet it provides opportunities to maintain a coherent framework for control over the law-making processes and the content of the legislation that is largely lacking under the American separation of powers model. While these qualities are under greater stress in New Zealand with MMP, they are values not to be abandoned lightly. They are certainly challenged by the "deemed regulations" developments.

The control over the law-making system exerted by the New Zealand Government through Cabinet is a valued and important part of the traditional protections available to New Zealanders. In particular, the fact that the Cabinet scrutinises all regulations is a significant protection against their excessive or inappropriate use. In the move to use rules, which lack the procedural protection of regulations, important constitutional

67 Legislation Advisory Committee "Legislative Change: Guidelines on Process and Content" para $114,36$. 
protections will be lost. There are risks of fragmentation, confusion and lack of democratic control over the content of the delegated legislation.

If we are not careful, New Zealand will move in the direction of the United States where the New Zealand equivalent of regulations are made by the Federal agencies themselves and are not subject to the scrutiny and control of a Cabinet system of Government. The Administrative Procedure Act 194660 Stat SAT327, 5 USCA $\S 553$ sets out the legal requirements for rule-making within the United States Government:

$\S 553$ Rule making

(a) This section applies, according to the provisions thereof, except to the extent that there is involved -

(1) a military or foreign affairs function of the United States; or

(2) a matter relating to agency management or personnel or to public property, loans, grants, benefits, or contracts.

(b) General notice of proposed rule making shall be published in the Federal Register, unless persons subject thereto are named and either personally served or otherwise have actual notice thereof in accordance with law. The notice shall include-

(1) a statement of the time, place, and nature of public rule making proceedings;

(2) reference to the legal authority under which the rule is proposed; and

(3) either the terms or substance of the proposed rule or a description of the subjects and issues involved. Except when notice or hearing is required by statute, this subsection does not apply -

(A) To interpretative rules, general statements of policy, or rules of agency organization, procedure, or practice; or

(B) when the agency for good cause finds (and incorporates the finding and a brief statement of reasons therefor in the rules issued) that notice and public procedure thereon are impracticable, unnecessary, or contrary to the public interest.

After notice required by this section, the agency shall give interested persons an opportunity to participate in the rule making through submission of written data, views, or arguments with or without opportunity for oral presentation. After consideration of the relevant matter presented, the agency shall incorporate in the rules adopted a concise general statement of their basis and purpose. When rules are required by statute to be made on the record after opportunity for an agency hearing, sections 556 and 557 of this title apply instead of this subsection. 
(d) The required publication or service of a substantive rule shall be made not less than 30 days before its effective date, except -

(1) a substantive rule which grants or recognizes an exemption or relieves a restriction;

(2) interpretative rules and statements of policy; or

(3) as otherwise provided by the agency for good cause found and published with the rule.

(C) Each agency shall give an interested person the right to petition for the issuance, amendment, or repeal of a rule.

Federal agencies must give public notice of what they intend to do, they must conduct hearings on it, but the agency itself makes the rule. As the years have gone on, rulemaking has become more and more widespread in the United States. Congress has frequently been able to state only the broad principles that it wants followed in primary legislation and has left the detail to be filled in by regulatory action.

A prominent administrative lawyer in the United States, Professor Jerry Mashaw of Yale Law School, has described the problem as follows: ${ }^{68}$

Statute after statute has declared that problem after problem would be solved through agency regulatory action, with scant appreciation of the scientific or political complexity of the task that was being set. Moreover, as it became clear that many of the objectives sought in this legislation would require massive research and development efforts, Congress has not responded with funding levels that would make accomplishment of its objectives feasible. But neither has it relaxed the statutory timetables or reduced the agenda previously set for agency attention. To some extent, therefore, the sense that agency rule-making is faltering is the result of ambitions that cannot possibly be met with the resources provided.

There is no doubt that the United States at both the federal and state level share with New Zealand a tendency to delegate more and more law making power to the executive branch of Government. As one of the leading American authorities on state administrative law has observed: ${ }^{69}$

It is clear that we live today in an administrative state, that is, in a society dominated by law created by administrative agencies. This situation is unlikely to change in the future. The process by which administrative agencies make law, therefore, is very important.

68 Jerry L Mashaw Greed, Chaos and Governance: Using Public Choice to Improve Public Law (Yale University Press, New Haven, 1997) 184.

69 Arthur Earl Bonfield State Administrative Rule Making (Little, Brown \& Company, Boston, 1986) (plus 1993 Supplement) 4, (original emphasis). 
If we have, to a large extent, substituted law made by administrative agencies for law made by legislatures in our society, we should ensure that the performance of that law making by agencies is fully legitimate because it is properly authorized by the elected representative of the people - the legislature. We should also ensure that the process by which agencies formulate and adopt that law is an adequate surrogate for the legislative process it replaces. More specifically, we should ensure that none of the essential functions of the legislative process are lost in the course of the performance by agencies of many law-making functions once performed by our legislatures.

There is more for New Zealanders to learn from state administrative law than federal in the United States due to the following factors:

- The smaller size of states;

- $\quad$ Fewer resources and less finance;

- The closeness of the regulators to the regulated in the states;

- Less legal assistance available;

- Greater contact with individuals who may not have lawyers rather than large organisations;

- The fact that the head of regulatory organisations may be employed part-time;

- The permissible range of complexity.

These differences suggest that the complexity and sophistication of the procedures must be scaled down in the states compared with what is required by federal law. ${ }^{70}$

\section{A Administrative Procedure Acts}

The National Conference of Commissioners on Uniform State Laws drew up model statutes in 1946, 1961 and 1981 the latest one called The Model State Administrative Procedure Act. ${ }^{71}$ The aim of the 1981 model was to create a political rule-making system that was rational in the sense that all the goals of regulation are clearly identified and the alternative means by which those goals may be realised. The model strikes a balance between procedures designed to ensure state agency rule-making is politically acceptable, technically sound, lawful and fair, and at the same time effective, efficient and economic. ${ }^{72}$

70 Bonfield above $n$ 69, 34 .

71 Uniform Law Commissioners' Model State Administrative Procedure Act (1981) (1990) 14 ULA 70.

72 Arthur Earl Bonfield "The Quest for an Ideal State Administrative Rulemaking Procedure" (1991) 18 Florida State L Rev 617. 
Currently the Administrative Procedure Acts (APA) of more than half of the fifty states are based in whole or in part on the 1961 model State Administrative Procedure Act, although a number of states have amended their APAs to reflect provisions of the 1981 model. ${ }^{73}$ Adoption of model laws always takes many years. When states developed their administrative law they adopted many of the general concepts of the 1946 Federal Administrative Procedure Act. But the connection with the Federal Act was indirect - the States relied directly on the model Acts. ${ }^{74}$ The general concepts adopted from the Federal APA are as follows: ${ }^{75}$

- Applications to all administrative bodies other than those specifically exempt;

- Division of agency actions into two classes - rule-making and adjudication with different procedures applicable to each class;

- Public access to all species of agency law created;

- Advance public notice of the content of proposed rules and opportunity for comment before adoption;

- Only one category of agency adjudication.

But there are also many differences between state and federal requirements. States are usually specific as to how far in advance a proposed rule must be published. States also confer an opportunity for oral proceedings in rule-making. The following analysis will deal with the 1981 model since that is the version that contains the most advanced thinking on what is appropriate for states. ${ }^{76}$ The prime features of the model scheme as it relates to rule-making from a New Zealand point of view are set out in the following numbered paragraphs:

1. A single statutory regime governing the making of all rules.

2. "Rule" means the whole or a part of an agency statement of general applicability that implements, interprets, or prescribes (i) law or policy, or (ii) the organisation, procedure or practice requirements of an agency. The term includes the amendment, repeal, or suspension of an existing rule.

73 Michael Asimow, Arthur Earl Bonfield, Ronald M Levin State and Federal Administrative Law (West Group, St Paul, 1998) 5.

74 Arthur Earl Bonfield "The Federal APA and State Administrative Law" (1986) 72 Virginia L Rev 297.

75 See above $\mathrm{n} 74$ for a lengthy analysis of all of these features.

76 Above $n$ 74, 334-335. 
3. The Act creates only procedural rights and duties. The Act applies unless another statute expressly supersedes it.

4. There are intricate requirements regarding appointment of an Administrative Rules editor, publication of rules, indexing and public inspection.

5. Proposed rules are required to be published.

6. Before it publishes a notice of a proposed rule, each agency may appoint a committee to comment on the subject matter of rule-making that is under consideration in the agency.

7. Each agency must maintain a current rule-making docket listing each pending rule-making proceeding and a number of specified details.

8. Before adoption of a rule an agency must give at least 30 days' notice of its contemplated action and include a short explanation of it, the legal authority authorising it, the text of the proposed rule, and where, when and how persons may present their views on it, and where they may demand an oral proceeding.

9. To afford an opportunity for allowing submissions in writing, argument, data and views, public participation is mandatory.

10. There must be an oral proceeding if it is requested in writing.

11. Each agency must have rules for the conduct of oral rule-making proceedings.

12. The agency is required to issue a regulatory analysis of a proposed rule if a written request is filed. This must include: a description of the persons affected, who will bear the cost and who will benefit; the quantitative and qualitative impact - economic or otherwise - upon affected persons; the probable costs to the agency and others of implementation and enforcement; comparison of costs and benefits of the proposed rule compared with costs and benefits of inaction; a determination of whether there are less costly and less intrusive methods of achieving the same purpose as the rule; a description of the alternative methods that were seriously considered and why they were rejected.

13. A summary of the regulatory analysis must be published along with an indication of where to get the full text.

14. An agency may not adopt a rule until the period for making written submissions and oral presentations has expired and it is obliged to consider the submissions and the regulatory analysis.

15. An agency cannot adopt a rule that is substantially different from the proposed rule. If it wants to do that it must start the process again. 
16. There is a general exemption from the public rule-making procedure where it would be unnecessary, impractical or contrary to the public interest. Where it is contested that exemption is appropriate the burden of proof is on the agency. There is provision for a rule-making proceeding to be held subsequently if the Governor requests.

17. A concise explanatory statement of the rule must be issued including the reasons for adopting it and any changes in text compared with the proposal.

18. These are requirements specified in the model statute as to contents, style and form of rules.

19. Each agency must maintain an official rule making record for each rule and the record and materials must be available for public inspection. What the record must contain is specified in detail.

20. Rules that do not comply with the Act can be declared invalid by the courts. Proceedings for non-compliance must be commenced within two years after the effective date of the rule.

21. There are special provisions for certain classes of rule - for example, internal management, staff guidelines, prices to be charged for goods and services sold by the agency, use of facilities and a number of other matters.

22. Any person may petition an agency requesting the adoption of a rule. The agency must within 60 days of submission of the petition deny it in writing with reasons or initiate rule-making proceedings.

23. At least annually, each agency shall review all of its rules to determine whether any new rule should be adopted. It must produce a written report with findings and reasons. Every seven years for each rule the report must include: (a) a concise statement of the rule's effectiveness; (b) criticisms of it received in the past seven years; (c) alternative solutions and why they were rejected.

24. The Governor of the State has power to rescind or suspend all or any severable portion of an agency rule by Executive order. He can also terminate rulemaking proceedings by the same means.

25. The Office of the Governor is required by the model law to have an administrative rules counsel to advise him.

26. The model law also enacts an Administrative Rules Review Committee of the legislature composed of three senators appointed by the President of the Senate and three representatives appointed by the Speaker of the House. 
27. The Legislative Committee can receive complaints from the public about possible, proposed or adopted rules and can hold hearings. It can make recommendations both about statutory changes and particular rules. The Committee can also file objections to a rule with the Secretary of State, in which case the agency must respond in writing. The Committee may withdraw or modify its objection after receiving the agency's response. But if it does not do so, the burden is on the agency in any proceeding for judicial review or for enforcement of the rule to establish that the rule is within the procedural or substantive authority delegated to the agency. The Committee may also recommend to an agency that it adopt a rule.

28. The model law itself provides the exclusive means of judicial review and there are some technical features relating to that contained in it. Final agency action is reviewable. Non-final agency action is also reviewable under some conditions. There is a liberal standing provision. Exhaustion of administrative remedies with the agency is a pre-requisite to judicial review. There are quite extensive provisions relating to the procedure for judicial review. The grounds of review are also specified. They are as follows:

§ 5-116(c) The court shall grant relief only if it determines that a person seeking judicial relief has been substantially prejudiced by any one or more of the following:

(1) The agency action, or the statute or rule on which the agency action is based, is unconstitutional on its face or as applied.

(2) The agency has acted beyond the jurisdiction conferred by any provision of law.

(3) The agency has not decided all issues requiring resolution.

(4) The agency has erroneously interpreted or applied the law.

(5) The agency has engaged in an unlawful procedure or decision-making process, or has failed to follow prescribed procedure.

(6) The persons taking the agency action were improperly constituted as a decision-making body, motivated by an improper purpose, or subject to disqualification.

(7) The agency action is based on a determination of fact, made or implied by the agency, that is not supported by evidence that is substantial when viewed in light of the whole record before the court, which includes the agency record for judicial review, supplemented by any additional evidence received by the court under this Act.

(8) The agency action is:

(i) outside the range of discretion delegated to the agency by any provision of law; 
(ii) agency action, other than a rule, that is inconsistent with a rule of the agency; [or]

(iii) agency action, other than a rule, that is inconsistent with the agency's prior practice unless the agency justified the inconsistency by stating facts and reasons to demonstrate a fair and rational basis for the inconsistency. [;or]

(iv) [otherwise unreasonable, arbitrary or capricious.]

If New Zealand continues with its growing tendency to make more rules as compared to regulations then the process will need to be made more formal and transparent than the existing separate statutory schemes. If that is the case, some generic statute governing all such rule-making along the lines of the Model State Administrative Procedure Act should be considered. If that is thought to be too elaborate, then there should be a return to what has been referred to in this article as the classical New Zealand system in which:

1. All regulations pass through Cabinet;

2. All regulations are drafted by Parliamentary Counsel;

3. All regulations are published in the Statutory Regulation series;

4. Rules and deemed regulations are abandoned.

What New Zealand has now is a three tiered system. The principles on which it is based have not been thought through. The processes that must be followed are not appropriate either. The rigour of the process laid down in the Land Transport Act provisions set out above is far less than for the Model State Administrative Procedure Act. Consultation provisions are not a substitute for the measured steps and openness of the American process. If law making is to be further delegated, then more protections are required than currently exist at the third level. But whether it is necessary and desirable to go to the third level at all needs to be seriously reconsidered.

\section{B Reg-Neg}

There has been another development in United States administrative law that may offer some assistance to New Zealand in deciding how to get out of the box that has been created by recent trends in delegated legislation. Negotiated rule-making takes place at both the federal and state level in the United States. The procedure is sometimes called "negotiated rule-making" or "reg-neg." Borrowed from the techniques of alternative dispute resolution it has been used to bring interested parties into the rule drafting process at an early stage under circumstances designed to foster cooperative solutions to regulatory problems. ${ }^{77}$ The process has a number of strengths. It can lead to better and

77 Administrative Conference of the United States, A Guide to Federal Agency Rulemaking (2 ed, 1991) 14549. See also David M Pritzker and Deborah S Dalton (eds) The Administrative Conference of the US, Negotiated Rulemaking Sourcebook (1995). 
more acceptable rules that are based on a clearer appreciation of the affected interests. Negotiated rules may also be easier to enforce and less likely to be challenged in litigation. There is opportunity for interchange between all affected parties. The Administrative Conference of the United States, a federal agency that existed from 1968 to 1995, consisted of about 100 experts in administrative law who volunteered their time to help improve administrative law. The Administrative Conference provided much of the initial impetus for the development which was viewed as permissible even without specific authorization. The Clinton Administration has been particularly keen on the "reg-neg" method of regulation.

The Negotiated Rulemaking Act of 1990 was enacted by Congress to encourage use of the technique. It was initially implemented on a temporary basis but Congress renewed it to continue indefinitely. ${ }^{78}$ The Act establishes a framework under which negotiated rulemaking takes place. The Act explicitly says it is not to be construed as an attempt to limit innovation and experimentation. An agency can establish a negotiated rule-making committee to negotiate and develop a proposed rule. ${ }^{79}$

The head of the agency must determine that such a process is in the public interest after considering a number of factors, the most important of which is that there are "a limited number of identifiable interests that will be significantly affected by the rule". 80 There must also be a reasonable likelihood that the committee can reach a consensus. Convenors may be retained to assist the agency and conduct discussions. When an agency decides to establish a negotiated rule-making committee the agency must publish, in the Federal Register and as appropriate in other publications, a notice of the committee, the scope of the rule to be developed and a list of the interests likely to be significantly affected, a work agenda, and a solicitation for comments on the proposal and proposed membership. ${ }^{81}$

The agency can decide to establish a committee if it determines, after receiving comments, that a committee can be adequately representative. Membership on the committee is limited by the Statute to $25 .{ }^{82}$ The agency must provide administrative support and technical assistance. In the deliberations, agency representatives participate and have the same rights and responsibilities as other members. Facilitators can be used. If the committee reaches a consensus on the proposed rule it must transmit a report containing the proposed rule to the agency. A committee terminates on promulgation of

\footnotetext{
785 United States Code Annotated §§561-70.

795 USCA $\S 561$.

805 USCA § 563

815 USCA $\S 564$.

825 USCA $\S 565$.
} 
the final rule. Generally, members of the committee are responsible for their own expenses. 83

Negotiated rule-making is clearly not suitable for all rule-making. The number of identifiable interests needs to be less than 25. A balanced committee that can negotiate in good faith may not always be possible. The possibility of delay may sometimes prevent use of the method. Whether the agency will be prepared to use consensus as the basis for the rule will also be a factor.

Many states have enacted legislation similar to the Negotiated Rulemaking Act. It appears that reg-neg comes more naturally to the states because it is less of a departure for them from the way they already operate. Informal negotiation is already a feature of the administrative process in many states. ${ }^{84}$

There are obvious dangers with reg-neg as well as advantages. Agreement may not remain within the confines of the regulatory power. Scientific information or statistics could be set to one side. The legitimacy of the rule flows from the agreement reached not the decision of the agency. There have been criticisms of the technique. ${ }^{85}$

One way out of the difficulties now emerging in New Zealand would be to use reg-neg for rules. Where consensus could not be reached then the Government could pass regulations in the ordinary way. Such a development would do less violence to the orthodox New Zealand law-making procedures than is being done by "deemed regulations".

\section{CONCLUSION}

New Zealand now has three categories of legislation: statutes, regulations and rules. The latter category has two divisions. Some are deemed to be regulations for all purposes. Others are deemed to be regulations for some purposes but not others. The prime reason for the development of rules is that they are easier to make than regulations. They offer fewer obstacles to the regulator although they may not necessarily be quicker than regulations because of statutory consultation provisions. The third class has existed for many years to a slight extent but it has now expanded to a degree that is threatening the integrity of what I have called the classical New Zealand system. That system can be characterised as follows.

835 USCA $\$ 568(\mathrm{c})$.

84 Henry H Peritt Jr "Negotiated Rulemaking in Administrative Law" (1986) 38 Admin L Rev 471, 474.

85 William Funk "Bargaining Towards the New Millennium: Regulatory Negotiation and the Subversion of the Public Interest" (1997) 46 Duke LJ 1351. There is a fascinating symposium on the topic of regulatory negotiation starting at (1997) 46 Duke LJ 1255. 
There are two classes of legislation: Acts of Parliament and Regulations. Both are printed by the Government and made available to the public in bound volumes. Regulations are made by the Governor-General in Council after being considered by Cabinet. They are drafted by Parliamentary Counsel. By way of contrast many categories of rules are not published in the same way as regulations. Secondly, they are not drafted by Parliamentary Counsel. The Chief Parliamentary Counsel in a submission to the Regulations Review Committee on deemed regulations stated: ${ }^{86}$

The amount of tertiary legislation drafted outside the Parliamentary Office is not known, but it is likely to be large and increasing.

Rules are made on the authority of one Minister only. They do not go to Cabinet.

The first issue is why New Zealand needs three levels of law-making rather than two. Such a development is neither desirable or necessary. The case for the new practice has not been made. Even if the case can be made, there needs to be some serious consideration given in relation to:

1. The procedures and processes to be followed in making rules, particularly Cabinet approval;

2. The drafting of the rules by Parliamentary Counsel;

3. The publication of the rules in the statutory regulation series.

Following American developments, one approach is to restrict the third category to measures that can be successfully negotiated to a consensus by the agency and those affected by the proposed rule. If that fails and coercive power is required then a regulation should be made. Another approach would be to require agreement of the full Cabinet to rules before they are made. The argument that Ministers are too busy cannot be sustained. Ministers need to take their obligations to scrutinise delegated legislation seriously and take responsibility for its contents. The task cannot safely be left to a single Minister relying on the advice of the regulatory agency. Under New Zealand's constitution Ministers as a group should take the responsibility. Ministerial responsibility offers a significant protection to the public against excessive regulatory zeal. Ex ante protections are helpful in making good law, but the protections offered by the Regulations Review Committee after a rule has been made are not sufficient.

It would also be helpful if the courts could be a little more robust in their approach to delegated legislation, particularly the third category, and apply unreasonableness tests to it in addition to ultra vires tests.

86 Submission 3. 
It is not the thesis of this article that regulation is unnecessary and that regulatory interventions are by definition undesirable. ${ }^{87}$ Rather, such interventions should be more carefully judged than they are in New Zealand. The New Zealand Government system still lacks both an intellectual and practical framework for arriving at those judgments within the Executive Government system. But there are dangers in entrusting too much power to public agencies. Recent developments in New Zealand show that we are heading in that direction. It is a tendency that has crept up on us incrementally. The coherence of our legal system is threatened by it.

Better machinery needs to be devised within the executive government to ensure that the collective interests of the government are being served by both proposed regulations and rules. There is a real danger that officials and drafters in departments and agencies capture both the process and the agenda. The issues raised here deserve serious policy attention but there is no government agency with the responsibility and the resource to do anything about it. Better advice systems are probably the most urgent need.

87 See generally Richard Epstein Simple Rules for a Complex World (Harvard University Press, Cambridge, 1995). 


\section{APPENDIX I}

\section{REGULATIONS REVIEW COMMITTEE REPORTS ON SPECIFIC MATTERS}

14 December 1998, AJHR I 16M

Report on a Complaint relating to the Legal Services Board (Civil and Criminal Legal Aid Remuneration) Instructions.

Recommendations: Committee found that the instructions did not breach any of the grounds in Standing Orders. Report drawn to the attention of the House.

Government Response: No response required.

1 September 1998, AJHR I 16K

Report on a Complaint relating to Land Transport Rule 32012-Vehicle Standards (Glazing).

Recommendations: Regulation drawn to the attention of the House. Rule should be redrafted.

Government Response: 1998, AJHR A 5. Accepted that rule should be redrafted and referred to the Committee.

\section{August 1998, AJHR I 16L}

Report on an Investigation into the Disputes Tribunals Amendment Rules 1997 and the Disputes Tribunals Amendment Rules 1998.

Recommendation: That 1998 rules be revoked, fees be reviewed and the issue of accessibility to the Tribunals be considered by the Government.

Government Response: 1998, AJHR A 5. Revocation of rules not necessary. Fees reconsidered.

10 August 1998, AJHR I 16J

Report on a Complaint relating to the Accident Compensation (Referred Treatment Costs) Regulations 1990.

Recommendations: Proposed Standard should be issued. Revocation of regulations not recommended

Government Response: 1998, AJHR A 5. Consultative process initiated.

21 July 1998, AJHR I $16 I$

Report on an Investigation into the Transport (Drivers Licensing) Amendment Regulations 1998. 
Recommendations: Extend consultative process to industry groups. Fee prescribed by regulation should be costed and made subject to regular reviews.

Government Response: 1998, AJHR A 5. Agreed with Committee on consultative process. Regular monitoring of licensing costs and fee changes.

29 June 1998, AJHR I 16H

Report on an Investigation into the Gaming and Lotteries (Licence Fees) Regulation 1997.

Recommendations: That the proposed bill include the power to make regulations setting differential fees. That the Government consider improving the fairness of gaming machine licence charges.

Government Response: 1998, AJHR A 5. Agreed to include in new legislation an amendment to increase flexibility in fee setting. Other proposals considered as part of new regulatory regime.

23 February 1998, AJHR I 16E

Report on an Investigation into the Biosecurity (Rabbit Calicivirus) Regulations 1997.

Recommendation: That the regulations be revoked and the matter dealt with in primary legislation.

Government Response: 1998, AJHR A 5. Did not agree with the Committee. Use of regulation as opposed to primary legislation justified.

23 February 1998, AJHR I 16F

Report on a Complaint relating to the Immigration Regulations 1991, Regulation 32B.

Recommendations: Revocation of regulation. General comment on immigration services.

Government Response: 1998, AJHR A 5. Support for two recommendations and qualified support for third.

\section{September 1997, AJHR I 16C}

Report on a Complaint relating to the Accident Rehabilitation and Compensation Insurance (Employment Premiums) Regulations 1995 and 1996.

Recommendations: The Corporation should consult on rates of premiums and classification matters.

Government Response: 1997, AJHR A 5. Had already taken action on the Committee's recommendations. 


\section{August 1997, AJHR I 16B}

Report on an Investigation into Children, Young Persons, and Their Families (Residential Care) Regulations 1996.

Recommendations: Legislation be enacted to replace regulations in relation to powers of search and seizure.

Government Response: 1997, AJHR A 5. Qualified support to two of three recommendations.

\section{July 1997, AJHR I 16A}

Report on a Complaint relating to Part 121 and Part 135 of the Civil Aviation Rules promulgated under section 28 of the Civil Aviation Act 1990.

Recommendations: That parts of the rules remain suspended and the intentions of the authorities be communicated to the aviation industry. Rules should not be made until primary legislation has been put into place.

Government Response: 1997, AJHR, A 5. Action taken on all recommendations.

\section{August 1996, AJHR I $16 L$}

Report on the Government's Response to the Report on the Complaint Relating to Staffing Orders, Promulgated Under Section 91H of the Education Act 1989, Affecting Area, Primary, Intermediate, and Secondary Schools.

Recommendations: That the Government implement the recommendations contained in the earlier report, which have not been adopted.

Government Response: 1997, AJHR I 20. Rejected Committee's view that it should negotiate with the PPTA.

\section{August 1996, AJHR I 16K}

Report on the Investigation into the Commencement of Legislation by Order in Council.

Recommendations: Incorporation of fixed commencement date on legislation. Commencement of legislation by Order in Council should be used in exceptional circumstances only.

Government Response: 1997, AJHR A 5. Agreed in principle to some recommendations.

\section{August 1996, AJHR I 16J}

Report on the Investigation into Access to Regulations 
Recommendations: That the Government improves access to delegated legislation. Expansion of the Tables of New Zealand Acts and Ordinances and Statutory Regulations in Force to include all delegated legislation. Registration of delegated legislation on an electronic database.

Government Response: 1996, AJHR A 5. Agreed in principle with the majority of regulations. Directed the Parliamentary Counsel Office to investigate issues before a final decision on the recommendations. Did not support idea of registration.

\section{June 1996, AJHR I 16H}

Investigation into the Citizenship Regulations 1978, Amendment No 6, Promulgated under the Citizenship Act 1977, and their impact on Children of Families Granted Entry to New Zealand on Humanitarian, Re-unification, or Refugee Grounds.

Recommendations: Fees for children applying for citizenship should be reduced, provisions for waiving fees should be included.

Government Response: Review of citizenship fees intended, recommendations would be taken into account at that time. Other recommendations merit further consideration.

\section{June 1996, AJHR I 16G}

Report on the Government's Response to the Inquiry of the Regulations Review Committee into the Resource Management (Transitional) Regulations 1994 and the Principles that Should be Applied to the Use of Empowering Provisions Allowing Regulations to Override Primary Legislation during a Transitional Period.

Recommendations: That the Government implement a consultative process and further controls be put in place prior to the promulgation of regulations that override the empowering Act.

Government Response: The Government did not agree with the general consultation requirement proposed by the Committee. Many statutes already require consultation to be undertaken as a prior step to the making of regulations. In cases where no consultation is required a statement detailing that fact and the reasons for it should be reflected in the Explanatory Note to the Bill.

\section{March 1996, AJHR I $16 F$}

Report on a Complaint Relating to Staffing Orders, Promulgated under Section 91H of the Education Act 1989, Affecting Area, Primary, Intermediate, and Secondary Schools.

Recommendations: Government should negotiate with affected parties. Primary legislation should be implemented to cover significant changes. A minority of the Committee disagreed. 
Government Response: 1997 AJHR A 5. Rejected negotiation option. Endorsed minority view.

\section{June 1995, AJHR I 16C}

Report on an Inquiry into the Resource Management (Transitional) Regulations 1994 and the Principles that Should Apply to the Use of Empowering Provisions Allowing Regulations to Override Primary Legislation During A Transitional Period.

Recommendations: A provision allowing for the making of regulations to amend the empowering Act should only be granted rarely and with strict controls.

Government Response: 1995, AJHR I 20. Agreed that statutory provisions permitting primary legislation to be modified by transitional regulations should be subject to a sunset clause of three years.

\section{November 1994, AJHR I 16B}

Report on the Complaints relating to the Accident Rehabilitation and Compensation Insurance (Counselling Costs) Regulations 1992.

Recommendations: Criteria and standards for the approval of counsellors should be reviewed.

Government Response: 1995, AJHR I 20. Government had already initiated a review of the ACC scheme.

6 October 1994, AJHR, I $16 B$

Report on a Complaint relating to the Whitebait Fishing (West Coast) Regulations 1994.

Recommendations: That the season be extended. Conservation Act 1987 be amended to allow for greater consistency in regulatory procedures. Undertake greater consultation and research to assist in determining the status of the fishery in the long-term.

Government Response: 1995, AJHR I 20. Season extended, acknowledged consultative process should be improved. Amendment to Conservation Act 1987 not appropriate.

30 September 1993, AJHR I 16K

Report on the Matter raised by Koru Aquaculture Ltd Relating to the Freshwater Fish Farming Regulations 1983, Amendment No 3.

Recommendations: Matter resolved. No requirement to report to the House. Committee questioned ongoing effects of the regulations. 
Government Response: Response not required.

19 August 1993, AJHR, I 16J

Report on the Complaint of Mrs Mary Bowers regarding the Marine Reserve (Whanganui a Hei (Cathedral Cove)) Order 1992.

Recommendation: That the Government review the current legislation and consider the criteria applicable to the Minister's discretion regarding objections. Public consultation required.

Government Response: Acknowledged that recommendations required consideration.

8 July 1993, AJHR I $16 I$

Report on the Inquiry into the Kiwifruit Marketing Regulations 1977, Amendment No 10.

Recommendations: That the amendment be revoked and the regulations enacted into primary legislation.

Government Response: Not located.

15 June 1993, AJHR I 16H

Report on Complaints relating to the Accident Rehabilitation and Compensation Insurance (Social Rehabilitation) Regulations 1992.

Recommendations: That all social rehabilitation regulations be reviewed within an adequate timeframe using an improved approach to consultation.

Government Response: 1993, AJHR I 20. Currently ensuring that all of the Committee's recommendations are followed.

23 December 1992, AJHR I 16G

Report on the Inquiry into the Accident Compensation (Accident Experience) Regulations 1992.

Recommendations: Employers should be consulted over the implementation of an accident experience rating system.

Government Response: 1993, AJHR, I 20. Had already commenced work on developing the regulations. Employers to be consulted on the form and content of the new regulations. 
19 November 1992, AJHR I 16F

Report on the Inquiry into the Accident Compensation Employers and Self-Employed Persons Levies Order 1991.

Recommendations: The regulations should be amended to reclassify the industrial activity of "Travel Agency".

Government Response: 1993, AJHR I 20. Industrial activity levy classes amended in accordance with the recommendation made by the Committee.

\section{August 1992, AJHR I 16}

Report on the Complaint of the New Zealand Educational Institute on the Accident Rehabilitation and Compensation Insurance (Earner Premium) Regulations 1992.

Recommendation: Where a new levy is imposed the statute should expressly provide for when that levy is to take effect.

Government Response: 1992, AJHR I 20. Agreed with recommendation.

22 August 1991, AJHR I 16D

Report on Two Complaints relating to the Lake Taupo Regulations 1976.

Recommendations: Legislation be amended to authorise harbour authorities to make bylaws which fix fees for the use of launching facilities. Regulation be amended. Fee structure be reviewed.

Government Response: 1991, AJHR, I 20. Amendment of legislation to be undertaken to reduce current non-compliance. Review of fee structure to be undertaken.

\section{August 1991, AJHR I 16C.}

Report on the Inquiry into the Marine Mammals Protection Regulations 1990.

Recommendations: Regulations be amended to include a clear statement of scope and purpose. Regulations should specify the criteria to be used by the Director-General in granting permits. A right of appeal should be included.

Government Response: 1991, AJHR, I 20. Proposed to incorporate most of the recommendations. Did not agree with right of appeal provision.

\section{May 1991, AJHR I 16B.}

Report on the Inquiry into the Civil Aviation Regulations 1953, Amendment No 31.

Recommendations: That regulations be amended. Greater consultation should be undertaken in the preparations of amendments. 
Government Response: 1991, AJHR I 20. Industry submissions sought before any amendments are made. Consultation procedures already in place.

\section{March 1991, AJHR I 16A}

Report on the Inquiry into the Accident Compensation Employers and Self-Employed Persons Levies Order 1990.

Recommendations: That the Government requests the Accident Compensation Corporation to add to the classifications contained in the regulation.

Government Response: 1991, AJHR I 20. Due to the significant practical and financial barriers the recommendations should be regarded as medium term in nature and would be taken into account in new legislation.

4 September 1990, AJHR, I16B

Report on the Inquiry into the Civil Aviation Charges Regulations 1990.

Recommendation: The Government should review the regulations or reconsider the manner in which fees and charges are set. Where there is greater than cost recovery from any party it must be transparent and authorised by legislation.

Government Response: Not located.

16 August 1990, AJHR, I 16

Report on the Inquiry into Airport Authority By-laws Approval Orders.

Recommendations: Amend legislation to ensure that the power to make by-laws is not vested in the hands of private companies. That a government agency be responsible for promulgating regulations in respect of matters which affect the movement of aircraft.

Government Response: Not located.

16 August 1990, AJHR, I 16

Report on the Government's Response to the Committee's Inquiry into the constitutional principles to Apply When Parliament Empowers the Crown to charge fees by regulation,

Recommendations: That the Government accord priority to the activity of the officials committee established to consider greater disclosure to facilitate parliamentary scrutiny of fees and charges set by statute.

12 July 1990, AJHR I 16

Report on the Inquiry into the Drafting of Empowering Provisions in Bill. 
Recommendations: Committee satisfied with the "formula" used by Parliamentary Counsel. Noted concern that empowering provisions not be used to broaden the scope of regulations.

Government Response: Response not required.

29 May 1990, AJHR I 16D

Report on the Inquiry into the Civil Aviation Regulations 1953, Amendment No30.

Recommendation: That the cost of the HURDA research be a cost paid from general taxation, not from licence fees.

Government Response: 1990, AJHR I 20. Accepted Committee's recommendation.

15 November 1989, AJHR I 16

Report on the Statutory Publications Bill.

Recommendations: Amendment of relevant Standing Orders to provide that notices of motion recommending the disallowance of regulations and affected by clause 93(1) of the Bill, remain on the Order Paper until dealt with by the House.

Government Response: Not located.

5 October 1989, AJHR I 16D

Report on the Government's Response to the Committee's Inquiry into the Reserve Bank of New Zealand Order 1988.

Recommendations: 1990, AJHR I 20. Committee's view had not changed.

Government response was inadequate.

25 July 1989, AJHR I 16C

Report on the Inquiry into the Constitutional Principles to Apply When Parliament Empowers the Crown to Charge Fees by Regulation.

Recommendations: That the House reaffirm its right to require the Crown to seek the prior authority of Parliament to extract from the public any money for the purposes of the Crown where the extraction is compulsory and enforceable by law. Standing Orders be amended to include a requirement that any Bill that quantifies fees, shall be accompanied by an explanatory note indicating whether the expected revenue will or will not exceed cost recovery.

Government Response: 1989, AJHR I 20. Agreed with Committee's aim for greater parliamentary scrutiny of fees and charges set by statutes or regulations. Did not consider 
it appropriate for Parliament to legislate on the contents of explanatory notes accompanying regulations. Officials committee established to consider matters.

\section{December 1988, AJHR I 16}

Report into the Inquiry into Fees Charged under the Weights and Measures Regulations 1987.

Recommendations: Regulations be amended to either exclude weighing machines from the regulations, or recognise the validity of accuracy issued by other countries.

Government Response: 1988, AJHR I 20. Drafting of legislative changes underway. New regulations to be added.

\section{December 1988, AJHR I 16B}

Inquiry into All Regulations in force as at 14 November 1988.

Recommendations: Identified regulations that were either obsolete or unnecessary.

Government Response: 1989, AJHR I 20. Favourable consideration given to recommendations. Some regulations would be revoked following further research.

\section{December 1988, AJHR I 16}

Report on the Inquiry into the Reserve Bank of NZ Order 1988.

Recommendation: That interim measures are imposed prior to amending legislation being brought before the House.

Government Response: 1989, AJHR I 20. Did not accept recommendations.

24 November 1988, AJHR I 16

Report on the Inquiry into the Appropriateness of Establishing the Kiwifruit Marketing Board through Regulations.

Recommendations: That the Board is established through primary legislation. Consolidation of Primary Products Marketing Act 1953 and Horticultural Export Authority Act 1987 into one piece of legislation.

Government Response: 1989, AJHR, I 20. Proposal to take action on one of the Committee's substantive recommendations. Did not accept that regulation should be revoked. Would consider repealing the 1953 Act.

\section{July 1988, AJHR I 16C}

Report on the Inquiry into the constitutional principles to apply when Parliament empowers the Crown to charge fees by regulation. 
Recommendations: Review of fees requiring parliamentary approval.

Government Response, 1989, AJHR I 20. Endorsed principles of Committee's report, greater financial disclosure desirable.

8 October 1987, AJHR I 16

Report on the Government's Response to the Committee's Inquiry into the Geothermal Energy Regulations 1961.

Recommendation: Government response failed to address the issues raised. Committee requested that the Government respond to the recommendations.

Government Response: Not located.

30 June 1987, AJHR I 16

Report on the Inquiry into the Geothermal Energy Regulations 1961.

Recommendations: That a regime be established for geothermal energy licences. Regulations be amended to charge all users rather than tappers.

Government Response: 1987, AJHR I 20. Satisfied as to the validity of the current regulations. Rejected recommendation to rebate rental charges. Accepted amendments to legislation to introduce consistent licensing mechanisms. 
